\title{
LIGHTWEIGHT AGGREGATES MADE FROM FLY ASH USING THE COLD-BOND PROCESS AND THEIR USE IN LIGHTWEIGHT CONCRETE
}

\author{
LAHKI AGREGATI IZDELANI IZ ELEKTROFILTRSKEGA PEPELA \\ S POSTOPKOM HLADNEGA VEZANJA IN NJIHOVA UPORABA \\ ZA LAHKE BETONE
}

\author{
Ana Frankovič', Violeta Bokan Bosiljkov' ${ }^{1}$, Vilma Ducman ${ }^{2}$ \\ ${ }^{1}$ University of Ljubljana, Faculty of Civil and Geodetic Engineering, Jamova 2, 1000 Ljubljana, Slovenia \\ ${ }^{2}$ Slovenian National Building and Civil Engineering Institute, Dimičeva 12, 1000 Ljubljana, Slovenia \\ vilma.ducman@zag.si \\ Prejem rokopisa - received: 2015-12-06; sprejem za objavo - accepted for publication: 2016-02-10
}

doi:10.17222/mit.2015.337

\begin{abstract}
Aggregates made from fly ash have been developed by means of the cold-bonding process, with the addition of Portland cement as a binder at $(10,20$, and 30$) \%$ of mass fractions, and by pouring the mixtures into moulds. After curing for $28 \mathrm{~d}$ the samples were processed into aggregate by crushing and sieving. An aggregate containing a weight percentage of $10 \%$ of cement was additionally produced by pelletization on a granulating plate. The density, water-adsorption capacity, porosity, compressive strengths, and frost resistance of the samples were determined. The aggregates prepared by both routes were then used to make concrete samples, whose properties were then compared to those of conventional concrete made using limestone aggregate. The compressive strength of the concrete made with the granulated aggregate reached $16.0 \mathrm{MPa}$ after $28 \mathrm{~d}$, whereas that of the concrete made with crushed aggregate amounted to $24.1 \mathrm{MPa}$, and that of the conventional concrete was $34.6 \mathrm{MPa}$.

Keywords: fly ash, lightweight aggregates, density, compressive strength, frost resistance
\end{abstract}

Agregati izdelani iz elektrofiltrskega pepela so bili razviti s postopkom hladnega vezanja, z dodatkom (10, 20 in 30) \% masnega deleža Portland cementa kot veziva in $\mathrm{z}$ ulivanjem mešanice $\mathrm{v}$ modele. Po 28 dnevnem strjevanju vzorcev so bili vzorci predelani $\mathrm{v}$ agregat $\mathrm{z}$ drobljenjem in sejanjem. Sestava, ki je vsebovala 10 masnih \% cementa, je bila še dodatno peletizirana na plošči za granuliranje. Določene so bile: gostota, kapaciteta absorpcije vode, poroznost, tlačna trdnost in odpornost na zamrzovanje. Sestave, izdelane na oba naćina, so bile uporabljene za izdelavo betonskih vzorcev, katerih lastnosti so bile primerjane z lastnostmi običajno izdelanega betona $\mathrm{z}$ uporabo sestave apnenca. Tlačna trdnost betona, izdelanega $\mathrm{z}$ granulirano sestavo, je dosegla 16,0 MPa po 28 dneh, medtem, ko je pri betonu izdelanem iz drobljenega agregata, znašala $24,1 \mathrm{MPa}$, pri običajnem betonu pa je bila 34,6 MPa.

Ključne besede: elektrofiltrski pepel, lahki agregati, gostota, tlačna trdnost, odpornost na zamrzovanje

\section{INTRODUCTION}

Although, if it has a suitable composition, fly ash can be added to cement to form a "blended cement", much of this ash is still deposited on landfill sites, causing an environmental burden. Apart from this, according to the European Waste Catalogue ${ }^{1}$ fly ash is labelled as hazardous waste, so that even higher costs are incurred for landfilling. Because of these facts, more and more scientists have been trying to find new ways in which such ash could be used, e.g., for the development of alkali-activated materials, which are frequently named geopolymers ${ }^{2,3}$, but also for the production of artificial aggregates. ${ }^{4-13}$ Artificial aggregates can be obtained simply by the crushing and grinding of industrial waste if the basic starting material is bulk waste. If, however, the basic starting material is a fine powder, such as fly ash, such aggregate can be produced by several different routes, as follows:

1) by high-temperature procedures, e.g., foaming and/or sintering at elevated temperatures of approx. 1200 ${ }^{\circ} \mathrm{C}$,
2) by a hydrothermal process at a temperature of approx.

$$
250{ }^{\circ} \mathrm{C} \text { (autoclaving), }
$$

3 ) by the cold bonding process, where consolidation takes place at room temperature.

In the last case a binding agent needs to be added to the mixture in order to achieve such consolidation. This agent is usually cement and/or water glass. ${ }^{14-18}$

In the first two processes a lot of energy is consumed, so that recently more effort has been put into investigations of cold-bonding processes.

The most common method for the preparation of aggregates from dust waste (e.g., fly ash) is granulation on a pelletization plate. The efficiency of granulation depends on the fineness of the fly ash, speed and time of rotation of the plate, as well as its inclination and the diameter of the plate ${ }^{8,12,15,19}$. From the point of view of costs, another more favourable method exists, in which there is no need for a pelletization plate, or for dry waste powder. This alternative method consists of mixing the raw material with a binder, and pouring the mixture into models. After the consolidation, setting, and hardening 


\section{A. FRANKOVIČ et al.: LIGHTWEIGHT AGGREGATES MADE FROM FLY ASH ...}

processes have been completed, the samples are crushed and sieved into different fractions.

Aggregates obtained in the above-described ways (especially granulation) almost always have lower densities. According to the definitions given in the standard EN 13055-1:2002 20, lightweight aggregates (LWAs) are those whose maximum particle density does not exceed $2000 \mathrm{~kg} / \mathrm{m}^{3}$, and whose loose bulk density does not exceed $1200 \mathrm{~kg} / \mathrm{m}^{3}$.

For some decades lightweight aggregates have been used in concrete instead of ordinary aggregates, mainly because of their contribution to the improvement of thermo-insulation properties. Apart from this, if LWAs are used, then a reduction can be achieved in the concrete's own weight, which can be important in earthquake-prone areas, as well as in cases where the subsoil beneath the foundations has a low bearing capacity. During the last decade much attention has been paid to the role of LWAs with open porosity in the internal curing of concrete. This is because lightweight aggregates with such porosity can serve as water reservoirs, which are available for later hydration, thus leading to higher compressive strengths. ${ }^{21-23}$ Many authors used lightweight aggregates made of fly ash in concreate to investigate the strength and durability of hardened concrete, and the influence of a lightweight fly-ash aggregate microstructure on the properties of concrete. ${ }^{24-29}$ As expected, the compressive strength of LWAC is lower than the one produced by natural aggregate, even though LWAC can anyway serve as a structural concrete. ${ }^{25}$ If fly-ash aggregate is sintered, it reaches a higher compressive strength of the aggregate itself, and consequently a higher compressive strength of the concrete is achieved. ${ }^{26}$ For cold bonded (non fired) aggregate it is also reported that chloride penetration could be somewhat higher. ${ }^{27}$ It is well recognized that by applying a sintering process the properties of LWAs are improved significantly, ${ }^{27,29}$ but it shall be noted that the firing process contributes to a much higher production cost, and on the other hand it negatively influences the environmental impacts (contributing to higher $\mathrm{CO}_{2}$ footprints).

The aim of the present work was to verify the usability of locally available fly ash (which due to the

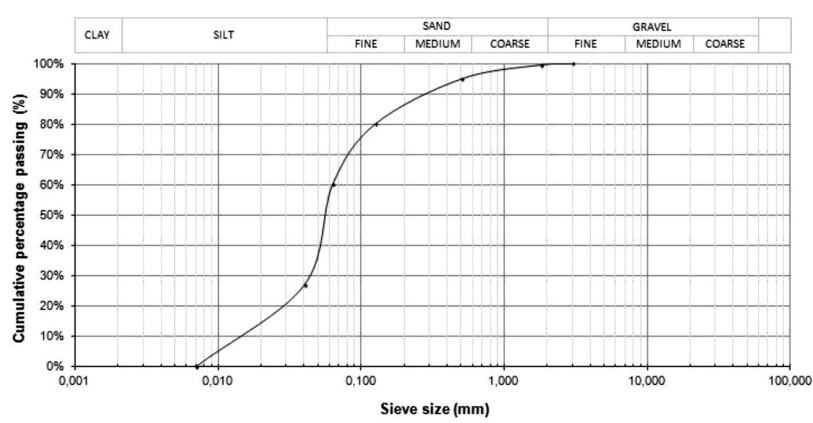

Figure 1: The sieving curve corresponding to the investigated fly ash Slika 1: Sejalna krivulja preiskovanega elektrofiltrskega pepela high loss on ignition is not suitable as an additive for cement) for the production of a lightweight aggregate, and to compare the results of the aggregate obtained by the granulation process to those obtained in the case when fly ash, together with a binding agent, is first poured into moulds and later crushed. The frost resistance of such an aggregate was also tested and optimised. The behaviour of both types of aggregate in the concrete matrix was also investigated.

\section{EXPERIMENTAL PART}

\subsection{Basic starting materials}

The basic starting material that was used to develop the investigated LWAs was fly ash, which was obtained as a by-product in the combustion of brown Indonesian coal. This particular type of fly ash contains only low amounts of sulphur. The results of a chemical analysis showed that this fly ash contains the following chemical components in the stated mass percentages: $\mathrm{SiO}_{2} 27.57$ $\%, \mathrm{Al}_{2} \mathrm{O}_{3} 8.37 \%, \mathrm{Fe}_{2} \mathrm{O}_{3} 16.24 \%, \mathrm{MgO} 7.06 \%, \mathrm{CaO}$ $22.99 \%, \mathrm{Na}_{2} \mathrm{O} 0.67 \%, \mathrm{~K}_{2} \mathrm{O} 2.67 \%$, and $\mathrm{TiO}_{2} 0.5 \%$. The loss on ignition amounts to $12.57 \%$. Because of its chemical composition, this type of fly ash is classified, according to EN 450-1 ${ }^{30}$, as an alumino-silicate fly ash. According to the results of a mineralogical analysis, it consists of a glassy phase $(67 \%)$, brownmillerite $(9.1$ $\%)$, quartz $(8.3 \%)$, lime $(6.1 \%)$, anhydrite $(3.2 \%)$, calcite, portlandite, and hematite.

The particle size distribution was determined by sieving the ash through sieves with diameters of $1.8 \mathrm{~mm}$, $0.5 \mathrm{~mm}, 0.125 \mathrm{~mm}, 0.063 \mathrm{~mm}$ and $0.04 \mathrm{~mm}$, as is shown in Figure 1. Most of the particles in the fly ash were smaller than $1 \mathrm{~mm}, 40 \%$ of them being smaller than $0.04 \mathrm{~mm}$. The Blaine finesse was determined according to EN 196-6 and it amounted to $2989 \mathrm{~cm}^{2} / \mathrm{g}$.

Table 1: Composition of mixtures for the preparation of the LWA Tabela 1: Sestava mešanic za pripravo LWA

\begin{tabular}{|c|c|c|c|c|}
\hline $\begin{array}{c}\text { Compo- } \\
\text { sition }\end{array}$ & Mixture & $\begin{array}{c}\text { Fly Ash } \\
(\mathrm{g})\end{array}$ & $\begin{array}{c}\text { Cement } \\
(\mathrm{g})\end{array}$ & Water $(\mathrm{g})$ \\
\hline PT1 & $\begin{array}{l}90 \% \text { FA + } \\
10 \% \text { CEM }\end{array}$ & 3600 & 400 & 2000 \\
\hline PT2 & $\begin{array}{l}80 \% \text { FA + } \\
20 \% \text { CEM }\end{array}$ & 3200 & 800 & 2000 \\
\hline PT3 & $\begin{array}{l}70 \% \text { FA + } \\
30 \% \text { CEM }\end{array}$ & 2800 & 1200 & 2000 \\
\hline GT1 & $\begin{array}{l}90 \% \text { FA + } \\
10 \% \text { CEM }\end{array}$ & 3600 & 400 & $\begin{array}{l}\text { Added as necessary } \\
\text { for the needs of the } \\
\text { granulation process }\end{array}$ \\
\hline
\end{tabular}

The binding agent cement CEM I was added in different proportions, as shown in Table 1. A Cementol Hiperplast 179 superplasticizer was also used.

For the frost-resistance improvement a commercial air entraining admixture Cementol ETA $\mathrm{S}$ was added. 
A. FRANKOVIČ et al.: LIGHTWEIGHT AGGREGATES MADE FROM FLY ASH ...

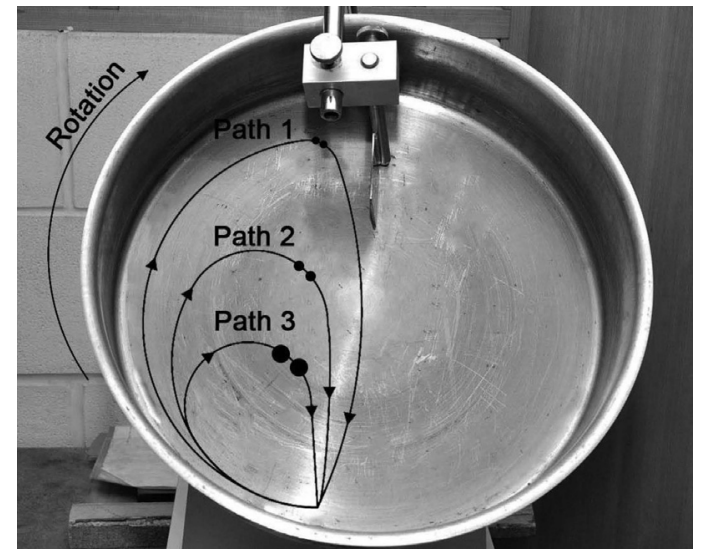

Figure 2: The granulating plate with a schematic presentation of the granulation process

Slika 2: Krožnik za granuliranje s shematskim prikazom procesa granulacije

\subsection{Procedures for the production of the investigated LWA}

The aggregates were produced by means of two different methods.

The aggregate that was designated "PT" was produced from prisms, which were made by first mixing the fly ash with the selected binder and water, and then pouring the mixture into standard mortar moulds. After curing in a climatic chamber at a temperature of $21{ }^{\circ} \mathrm{C}$ and a relative humidity of $94 \%$ for $28 \mathrm{~d}$, the prisms were crushed and then sieved into fractions of $0-1 \mathrm{~mm}, 1-2$ $\mathrm{mm}, 2-4 \mathrm{~mm}$, and $4-8 \mathrm{~mm}$. The aggregate that was designated "GT" was produced by the pelletization procedure $^{31}$, using a rotating plate (Figure 2).

During the granulation phase the tilting angle was fixed at $60^{\circ}$, the mixer speed was $48 \mathrm{~min}^{-1}$, and the mixing time was $2 \mathrm{~min}$. The fly ash had been previously mixed with cement, and was then poured slowly onto the plate. During the granulation process, water droplets were added by spraying.

Both types of aggregate are shown in Figure 3a (the PT aggregate) and $\mathbf{3 b}$ (the GT aggregate).

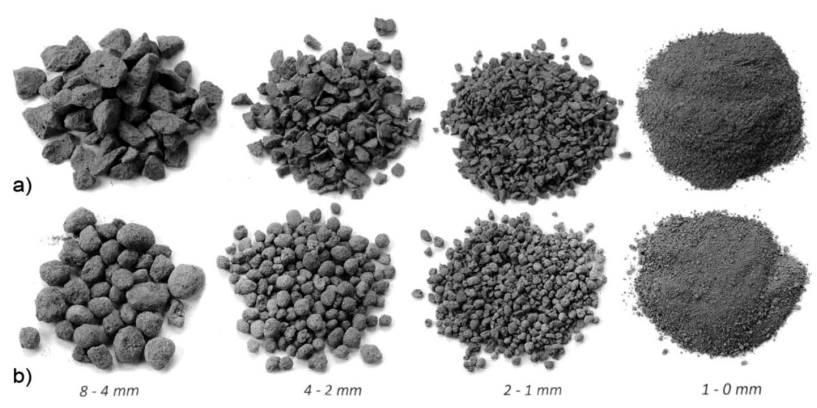

Figure 3: The final products: a) PT- made from crushed aggregate and b) GT- made from granulated aggregate

Slika 3: Končni proizvodi: a) PT - izdelan iz zdrobljenega agregata in b) GT - izdelan iz granuliranega agregata
Normal-weight aggregate, i.e., dense limestone aggregate from the Laže quarry in SW Slovenia, was used for the preparation of the blank concrete samples.

\subsection{Characterization of the investigated aggregates}

The porosity, pore size distribution, apparent density, and bulk density of the prepared aggregates were determined by means of mercury intrusion porosimetry (MIP). Particles having a size of approximately $1 \mathrm{~cm}^{3}$ for each of the prepared artificial aggregates were dried in an oven for $24 \mathrm{~h}$ at $110^{\circ} \mathrm{C}$, and then analysed by means of MIP Autopore IV 9500 equipment (Micrometrics).

The microstructure of the polished cross-sections of the aggregate samples were examined using the backscattered electron (BSE) image mode of a low-vacuum scanning electron microscope (SEM) using JEOL 5500 LV equipment.

The water absorption of all three types of crushed aggregate (PT1, PT2, PT3) and of the granulated aggregate was determined by measuring the dry mass $m_{\mathrm{dry}}$ and the wet mass after immersion for $24 \mathrm{~h}$ in water (this is the saturated surface-dry mass $\left.m_{\text {sat }}\right)$. It was calculated from Equation (1):

$$
W=\frac{m_{\text {sat }}-m_{\text {dry }}}{m_{\text {dry }}} \cdot 100
$$

The mechanical properties of the prisms were evaluated according to EN 196-1:2005 $5^{32}$, whereas the compressive strength of the granules was determined after curing the granulates in a climatic chamber at $21^{\circ} \mathrm{C}$ and a relative humidity of $94 \%$ for $28 \mathrm{~d}$, according to the procedure described by C. R. Cheeseman ${ }^{5}$, where individual granules are loaded to failure between two parallel plates. For the calculation of the compressive strength the following Equation (2) was used:

$$
R_{\mathrm{c}}=\frac{2,8 \cdot F_{\mathrm{c}}}{h^{2} \cdot \pi}
$$

where $F_{\mathrm{c}}$ is the load causing failure (i.e., fracture), $\mathrm{h}$ is the spherical diameter of the granule, and the value of 2.8 is a shape factor.

The frost resistance of the aggregate was determined according to EN 13055-1:2002 ${ }^{20}$ on two parallels, where in each parallel $400 \mathrm{~g}$ of dry samples (mass $M_{1}$ ) of the fraction 4-8 $\mathrm{mm}$ was immersed in water for $4 \mathrm{~h}$. After that the samples were exposed to 20 cycles of freezingthawing, from $-18{ }^{\circ} \mathrm{C}$ to $+18{ }^{\circ} \mathrm{C}$. After 20 cycles the samples were dried and sieved through a sieve with apertures of $2 \mathrm{~mm}$. The remains on the sieve represent the mass $\mathrm{M}_{2}$. The percentage of mass loss due to the freezing action $(\mathrm{F})$ is calculated using Equation (3):

$$
F=\frac{M_{1}-M_{2}}{M_{2}} \cdot 100
$$




\section{MATERIALI IN TEHNOLOGIJE/MATERIALS AND TECHNOLOGY (1967-2017) - 50 LET/50 YEARS}

\section{A. FRANKOVIČ et al.: LIGHTWEIGHT AGGREGATES MADE FROM FLY ASH ...}

The mechanical properties of the prisms were determined by means of a $300-\mathrm{kN}$ ToniNorm compression testing machine.

The bulk densities and strength tests of the concrete samples were determined on standard prisms for mortars of $(4 \times 4 \times 16) \mathrm{cm}$.

\subsection{Preparation of the fly-ash aggregate concrete mixes}

The compositions of the concrete mixes that were prepared from the two different types of artificial aggregate (PT1-C, and GT1-C), and that of the mix made using natural limestone aggregate (LMS-C), are shown in Table 2.

Table 2: Composition of the concrete specimens made by different types of aggregate

Tabela 2: Sestava betonskih vzorcev, izdelanih z različnimi vrstami agregatov

\begin{tabular}{|c|c|c|c|}
\hline Sample designation & PT1-C & GT1-C & LMS-C \\
\hline Type of aggregate & crushed & granulated & crushed \\
\hline \multicolumn{4}{|l|}{ Mass $(\mathrm{g})$} \\
\hline Aggregate & 5188 & 3269 & 9595 \\
\hline Cement & 1505 & 1505 & 1505 \\
\hline Fly ash & 645 & 645 & 645 \\
\hline Water in the aggregate & 917 & 1531 & 0 \\
\hline Added water & 1110 & 769 & 1227 \\
\hline Super plasticizer & 7.5 & 7.5 & 7.5 \\
\hline \multicolumn{4}{|l|}{$w / c$ ratio } \\
\hline $\begin{array}{c}w / c \text { ratio (with water in } \\
\text { the aggregate) }\end{array}$ & 0.94 & 1.07 & 0.57 \\
\hline $\begin{array}{c}w / c \text { ratio (without } \\
\text { water in the aggregate) }\end{array}$ & 0.52 & 0.36 & 0.57 \\
\hline
\end{tabular}

The contents of the individual fractions of the aggregates were determined according to the curves specified in the standard SIST 1026:2008 ${ }^{33}$ (curve B for the crushed aggregate, and curve A for the granulated aggregate (Figure 4)).

Because of the high water absorption of the lightweight aggregates, prior to mixing they were immersed in water for $30 \mathrm{~min}$ and then drained in order to remove

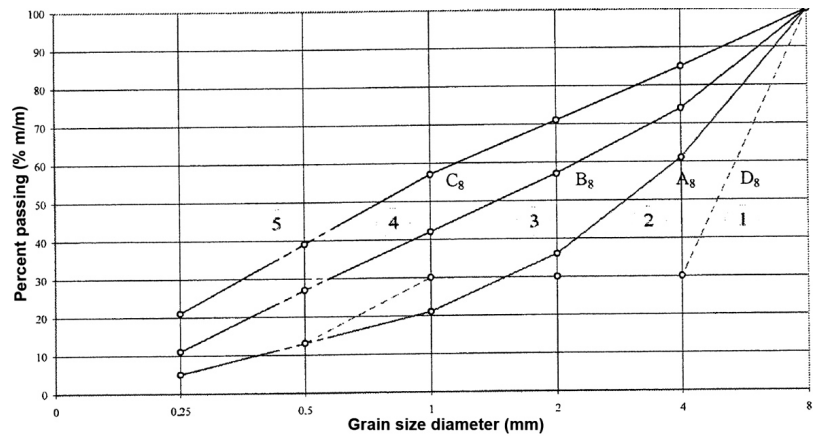

Figure 4: Recommended sieve curves for $0 / 8 \mathrm{~mm}$ aggregate mixtures taken from SIST 1026:2008 ${ }^{33}$

Slika 4: Priporočene sejalne krivulje za $0 / 8$ mm mešanico agregatov, vzeta iz SIST 1026:2008 33 the surface water. Taking into account the k-value concept for the fly ash (according to EN 206: 201334), a maximum of $30 \%$ of the cement binder was replaced by fly ash as an additive. Compressive strength tests according to the standard EN 196-1:2005 ${ }^{32}$, as well as density tests, were performed on hardened test specimens after $(7,28$, and 90) days. In all cases the test specimens were cured in a climatic chamber at a temperature of $21{ }^{\circ} \mathrm{C}$ and a relative humidity of $94 \%$.

\section{RESULTS}

\subsection{Characterization of the aggregates}

The densities and porosities of the investigated aggregates, determined by MIP, are shown in Table 3 . The pore size distributions for the artificial aggregates are shown in Figure 5.

Table 3: Density and porosity of the investigated aggregates, as determined by MIP

Tabela 3: Gostota in poroznost preiskovanih agregatov, določene z MIP

\begin{tabular}{|c|c|c|c|c|c|c|}
\hline $\begin{array}{c}\text { Sample } \\
\text { designa- } \\
\text { tion }\end{array}$ & $\begin{array}{c}\text { Total } \\
\text { intrusion } \\
\text { volume } \\
\left(\mathrm{cm}^{3} / \mathrm{g}\right)\end{array}$ & $\begin{array}{c}\text { Total } \\
\text { pore } \\
\text { area } \\
\left(\mathrm{m}^{2} / \mathrm{g}\right)\end{array}$ & $\begin{array}{c}\text { Average } \\
\text { pore } \\
\text { diameter } \\
(\mu \mathrm{m})\end{array}$ & $\begin{array}{c}\text { Bulk } \\
\text { density } \\
\left(\mathrm{g} / \mathrm{cm}^{3}\right)\end{array}$ & $\begin{array}{c}\text { Apperent } \\
\text { density } \\
\left(\mathrm{g} / \mathrm{cm}^{3}\right)\end{array}$ & $\begin{array}{c}\text { Porosity } \\
(\%)\end{array}$ \\
\hline PT1 & 0.3899 & 33.171 & 0.047 & 1.182 & 2.1923 & 46.08 \\
\hline PT2 & 0.3710 & 46.925 & 0.0316 & 1.258 & 2.359 & 46.67 \\
\hline PT3 & 0.3178 & 50.231 & 0.0253 & 1.333 & 2.313 & 42.37 \\
\hline GT1 & 0.6429 & 31.4 & 0.0819 & 0.9195 & 2.2487 & 59.11 \\
\hline
\end{tabular}

If the results obtained for the aggregates PT1, PT2, and PT 3 are compared, it can be seen that in the case of a higher amount of added binder (cement), the density of the aggregate is higher, and the porosity is lower. It can be further seen, comparing GT1 and PT1, that the granulated aggregate has a lower density and higher porosity than the crushed aggregate.

For instance the density of the granulated aggregate was $0.9 \mathrm{~g} / \mathrm{cm}^{3}$, whereas that of the aggregates obtained by crushing was significantly higher, i.e., $1.2 \mathrm{~g} / \mathrm{cm}^{3}$. However, both of these two aggregates, i.e., PT1 and

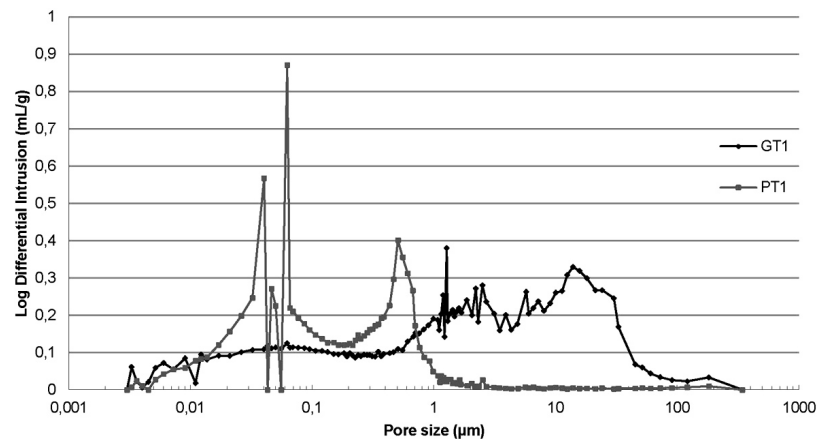

Figure 5: Measured pore size distribution for the two artificial aggregates

Slika 5: Izmerjena razporeditev velikosti por v dveh izdelanih agregatih 
GT1, can be classified as lightweight aggregates according to EN 13055-1:2002. ${ }^{20}$ The measured porosity of the aggregate PT1 was found to be equal to $46.1 \%$, whereas that of the aggregate GT1 amounted to $59.1 \%$.

From Figure 5 it can be seen that, in the case of aggregate PT1, almost all the pores have sizes of less than $1 \mu \mathrm{m}$, the average pore size being $0.047 \mu \mathrm{m}$, whereas in the case of aggregate GT1, the pore sizes ranged between $0.003 \mu \mathrm{m}$ and $100 \mu \mathrm{m}$. The average pore size of aggregate GT1 was $0.082 \mu \mathrm{m}$.

The measured water absorption of the crushed aggregate was, as expected from the density of the aggregates, less than that of the granulated aggregate. In the case of the aggregate sample PT1 the water absorption amounted to $38.4 \%$ (in the case of the samples PT2 and PT3: $35.9 \%$ and $30.7 \%$ respectively), whereas in the case of aggregate sample GT1 it amounted to $57.8 \%$. According to these results the porosity of the aggregates can be classified as being open. It is clear that the content of the binder has an effect on the water absorption of the aggregate.

The results of the tensile and compressive strength tests performed on the aggregates are presented in Table 4. As could be expected, the results show that the crushing strength increases with the binder content. The tensile strength of the crushed aggregates (samples PT1, PT2, PT3) ranged between 2.2 $\mathrm{MPa}$ and 4.6 MPa, whereas their compressive strengths ranged between 12.6 $\mathrm{MPa}$ and $30.6 \mathrm{MPa}$. In the case of the granulated aggregate granules (sample GT1) only the compressive strength was determined, by measurements that were performed on single granules. For this reason the value cannot be directly compared to the values obtained in the case of the PT samples. It amounted to $0.96 \mathrm{MPa}$.

Table 4: Crushing strengths of the aggregate samples

Tabela 4: Trdnost vzorcev agregatov pri drobljenju

\begin{tabular}{|c|c|c|c|c|}
\hline & \multicolumn{2}{|c|}{ Bending strength } & \multicolumn{2}{c|}{ Compressive strength } \\
\hline $\begin{array}{c}\text { Sample } \\
\text { designa- } \\
\text { tion }\end{array}$ & $\begin{array}{c}\text { after 7 d } \\
\text { curing at } \\
94 \% \\
\text { humidity } \\
\text { (MPa) }\end{array}$ & $\begin{array}{c}\text { after 28 d } \\
\text { curing at } \\
94 \% \\
\text { humidity } \\
(\mathrm{MPa})\end{array}$ & $\begin{array}{c}\text { after 7 d } \\
\text { curing at } \\
94 \% \\
\text { humidity } \\
(\mathrm{MPa})\end{array}$ & $\begin{array}{c}\text { after 28 d } \\
\text { curing at } \\
94 \% \\
\text { humidity } \\
(\mathrm{MPa})\end{array}$ \\
\hline PT1 & 2.1 & 2.2 & 6.8 & 12.6 \\
\hline PT2 & 2.9 & 3.2 & 11.1 & 18.6 \\
\hline PT3 & 4.1 & 4.6 & 19.5 & 30.6 \\
\hline GT1 & $/$ & $/$ & $/$ & 0.96 \\
\hline
\end{tabular}

The results of the SEM investigation confirmed the differences in the microstructure between the crushed aggregate and the granulated aggregate. The microstructure of sample PT1 was found to be more homogeneous than that of sample GT1 (Figure 6). In both figures grains of fly ash can still be seen. In the case of sample GT1 several smaller granules are bonded together to form a larger granule, with large associated air pores inside, which contributes to the higher porosity of the granulated aggregate.
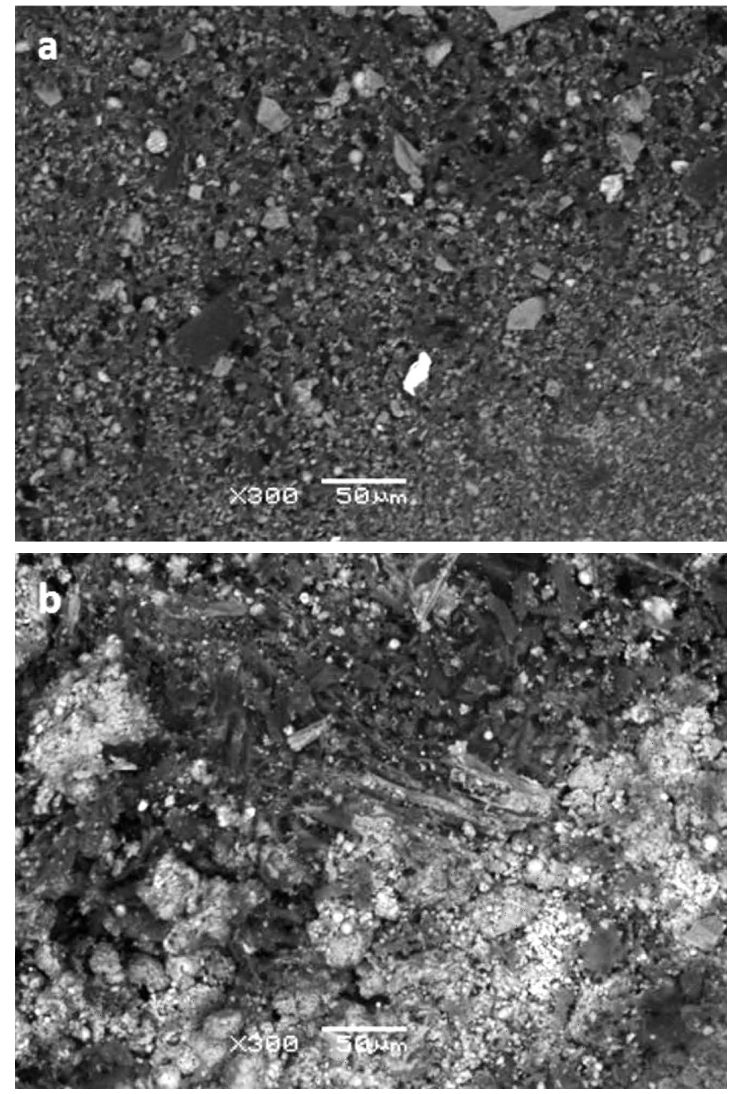

Figure 6: BSE SEM images of samples: a) PT1 and b) GT1of the investigated aggregates, shown at the same magnification

Slika 6: BSE SEM-posnetek vzorcev: a) PT1 in b) GT1, preiskovanih agregatov, prikazanih pri enaki povečavi

Comparing the properties of the granulated aggregate to the properties of the crushed aggregate it can be noted that the crushed aggregate has better mechanical properties and a lower porosity, which could be partially ascribed to the process of pelletization (if not all the parameters are optimal), but also to the fact that during pelletization the $w / c$ factor is not uniformly distributed throughout the single granules of aggregate, which introduce weak points at the microstructural level. By the mixing, pouring and crushing process of aggregate production a more uniform $\mathrm{w} / \mathrm{c}$ and microstructure of aggregate is obtained.

\subsection{Characterization of the hardened concrete test specimens}

In Table 5, the results for the compressive and bending strengths are presented for hardened test specimens of the concrete mixes, which were made from LWAC, whose preparation is defined in Table 2. The strength of the concrete made with limestone aggregate is higher than that of the concrete made using the artificial LW crushed or granulated aggregate, despite the highest water-to-cement ratio. However, when crushed aggregate is used, the bending and compressive strengths of the hardened concrete made from them are consider- 


\section{MATERIALI IN TEHNOLOGIJE/MATERIALS AND TECHNOLOGY (1967-2017) - 50 LET/50 YEARS}

\section{A. FRANKOVIČ et al.: LIGHTWEIGHT AGGREGATES MADE FROM FLY ASH ...}

ably higher than those that can be achieved with granulated aggregate. This is confirmed by the results that are shown in Table 5, where, despite the much lower water-to-cement ratio of test specimen GT1-C (0.36), the obtained strengths are still much lower than those corresponding to test specimen PT1-C, which had a water-to-cement ratio of 0.52 .

Table 5: Determined compressive and tensile strengths of the concrete test specimens

Tabela 5: Določene tlačne in upogibne trdnosti preizkušanih vzorcev betona

\begin{tabular}{|c|c|c|c|c|}
\hline \multicolumn{2}{|c|}{ Test specimen designation } & PT1-C & GT1-C & LMS-C \\
\hline \multirow{2}{*}{$\begin{array}{c}\text { Tensile } \\
\text { strength } \\
\text { (MPa) }\end{array}$} & $\begin{array}{c}\text { after 7 d curing at } \\
94 \% \text { humidity }\end{array}$ & 2.9 & 2.6 & 5.6 \\
\cline { 2 - 5 } & $\begin{array}{c}\text { after 28 d curing at } \\
94 \% \text { humidity }\end{array}$ & 3.5 & 2.7 & 6.4 \\
\cline { 2 - 5 } $\begin{array}{c}\text { after 90 d curing at } \\
94 \% \text { humidity }\end{array}$ & 3.6 & 2.8 & 7.4 \\
\hline \multirow{2}{*}{$\begin{array}{c}\text { Compres- } \\
\text { sive } \\
\text { strength } \\
\text { (MPa) }\end{array}$} & $\begin{array}{c}\text { after 7 d curing at } \\
94 \text { humidity }\end{array}$ & 19.0 & 13.5 & 28.7 \\
\cline { 2 - 5 } & $\begin{array}{c}\text { after } 28 \text { d curing at } \text { humidity } \\
94 \% \text { d curing at }\end{array}$ & 24.1 & 16.0 & 34.6 \\
\hline \multirow{2}{*}{$\begin{array}{c}94 \text { humidity } \\
\text { after }\end{array}$} & 25.3 & 17.1 & 40.5 \\
\hline
\end{tabular}

The density of the concrete made with crushed aggregate amounted to $1610 \mathrm{~kg} / \mathrm{m}^{3}$, whereas that of the concrete made with granulated aggregate was $1490 \mathrm{~kg} / \mathrm{m}^{3}$. As expected, the density of the concrete made with natural limestone aggregate (LMS-C) was much higher, and amounted to $2290 \mathrm{~kg} / \mathrm{m}^{3}$ (Table 6).

Generic values for the thermal properties can be obtained from the standard EN 1745:2012 $2^{34,35}$ (Table A.9 for lightweight aggregate concrete, and Table A.2 for dense aggregate concrete) - the assigned values for the different types of concrete prepared within the scope of this investigation are also given in Table 6.

Table 6: Density of the different types of concrete together with the corresponding thermal properties, based on the generic values given in the standard EN $1745^{35}$

Tabela 6: Gostota različnih vrst betonov skupaj z njihovimi toplotnimi lastnostmi, na osnovi generičnih vrednosti danih $\mathrm{v}$ standardu EN $1745^{35}$

\begin{tabular}{|c|c|c|c|c|}
\hline \multicolumn{2}{|c|}{ Sample designation } & PT1-C & GT1-C & LMS-C \\
\hline $\begin{array}{c}\text { Density } \\
\left(\mathrm{kg} / \mathrm{m}^{3}\right)\end{array}$ & $\begin{array}{c}\text { After 90 d } \\
\text { curing }\end{array}$ & 1610 & 1490 & 2290 \\
\hline $\begin{array}{c}\lambda_{10, \text { dry }} \\
(\mathrm{W} / \mathrm{mK})\end{array}$ & $\begin{array}{c}\text { Acc. to EN } \\
1745\end{array}$ & 0.84 & 0.73 & 1.36 \\
\hline
\end{tabular}

According to the properties obtained in the case of test specimen PT1-C (a tensile strength of $3.5 \mathrm{MPa}$, a compressive strength of $24.1 \mathrm{MPa}$, and a density of 1610 $\mathrm{kg} / \mathrm{m}^{3}$ ), this type of concrete can be classified as a medium-strength concrete with a low density and improved thermal insulation properties.

SEM investigations of the concrete did not show significant differences in the microstructures of the concrete that had been made with crushed aggregate or
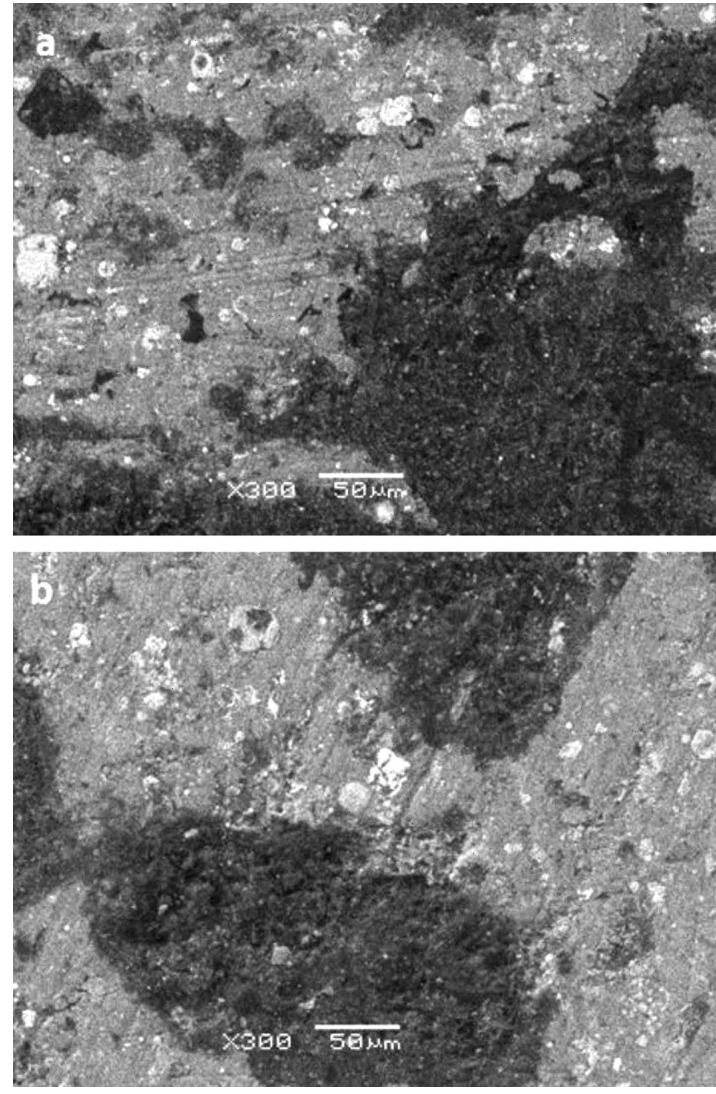

Figure 7: BSE SEM-images of: a) the test specimens PT1-B and b) GT1-B, shown at the same magnification

Slika 7: BSE SEM-posnetek preizkusnih vzorcev: a) PT1 - B in b) $\mathrm{GT} 1-\mathrm{B}$, prikazan pri enaki povečavi

granulated aggregate (Figure 7). The observed cement matrix is homogeneous with relicts of portlandite, and adhered well to the aggregate. Interlocking of the cement matrix with the porous crushed aggregate (PT1), where the cement paste entered the crushed grains, was more pronounced than in the case when the rounded granulated aggregate (GT 1) was used. ${ }^{36}$

\subsection{Determination and optimization of aggregate frost resistance}

The frost resistance of an aggregate depends to a large extent on the pore structure of its grains. It is well-known that aggregates with a lower porosity and a greater proportion of fine pores possess better frost resistance. ${ }^{37}$

The results of the tests that were performed in order to determine the frost resistance of the investigated aggregate indicated a significant loss of mass upon freezing (Table 7), which was especially severe in the case of the granulated aggregate (GT1), where the loss of mass amounted to $96.7 \%$. The very high loss of mass $(96.7 \%)$ on freezing of the granulated fly ash aggregates could be ascribed to the very high porosity (water absorption of $57.8 \%$ ) and the very low crushing strength (0.96 MPa). 
Samples that were obtained by pouring the mixtures into moulds, and after that crushing and sieving (they were designated PT), resulted in a somewhat improved frost resistance due to the lower initial porosity, as well as better mechanical properties. However, in this case, too, the loss of mass was significant (from $19.1 \%$ to $31.5 \%$ ). In the case of sample PT 1 improvements in the frost resistance were searched for in two directions. In the first test (sample PT 1a), the fly ash was additionally sieved onto a $0.125 \mathrm{~mm}$ sieve (in this way the majority of the organic particles were removed; loss on ignition decreased from the original value of $10.17 \%$ to $3.3 \%$ ), and then processed in the same way as PT 1 . In second test (sample PT 1+ ETA S) the sample of fly ash was not additionally processed by sieving, but instead a commercially available air entraining admixture (normally used for the improvement of the frost resistance of concrete) was added, whose mass amounted to $0.1 \%$ of the mass of the cement. Both approaches significantly improved the frost resistance of the aggregate. The sieving away of particles above $0.125 \mathrm{~mm}$ resulted in a mass loss of $8.1 \%$ after freezing thawing, whereas the adding of an air-entrapping agent resulted in a mass loss of $1.8 \%$ after freezing.

Table 7: Loss of mass after 20 cycles of freezing-thawing Tabela 7: Izguba mase po 20 ciklih zmrzovanja-taljenja

\begin{tabular}{|c|c|}
\hline Sample designation & Loss of mass (\%) \\
\hline GT1 & 96.7 \\
\hline PT1 & 19.1 \\
\hline PT1a & 8.1 \\
\hline PT2 & 31,5 \\
\hline PT3 & 25,9 \\
\hline PT1+ETA S & 1,8 \\
\hline
\end{tabular}

\section{CONCLUSIONS}

Based on the results of the performed investigations, it can be concluded that in the case of pouring and crushing (PT), aggregates of higher density and strength can be obtained in comparison with aggregates that can be obtained by granulation (GT). In the case of crushing, polygonally shaped aggregates are obtained, which can improve the interlocking effect with the cement matrix.

Both of the two types of investigated aggregate (PT and GT) were highly porous (with porosities of $38.4 \%$, and $57.8 \%$, respectively), and their porosity was of the open type. In such cases water can be stored within the aggregate grains, which can then be available for subsequent hydration. Open porosity can also contribute to a stronger interfacial zone between the aggregate and the cement matrix.

The frost resistance of such aggregates is influenced by their content of organic particles, but it can be significantly improved by removing part of the organic particles and /or by adding a commercially admixture for frost-resistance improvement.

The application of such aggregates in concrete has confirmed their usability in the construction sector by the utilization of nearly $80 \%$ of fly ash in concrete (partly as an additive to cement, with its main share in the aggregate).

The methodology described in the paper for the use of fly ash could also be used for other kinds of waste dust that are generated, for example, in the construction industry, in agriculture, and in the refractory industry.

\section{Acknowledgements}

This work was financially supported by the Slovenian Research Agency Programme Group P2-0273.

\section{REFERENCES}

${ }^{1}$ Environmental Protection Agency, European waste catalogue and hazardous waste list (valid from 1 January 2002), http://www.nwcpo.ie/forms/EWC_code_book.pdf/

${ }^{2}$ A. Palomo, M. W. Grutzeck, M. T. Blanco, Alkali-activated fly ashes: A cement for the future, Cement and Concrete Research, 29 (1999), 1323-1329, doi:10.1016/S0008-8846(98)00243-9

${ }^{3}$ J. L. Provis, J. S. J. Van Deventer, Alkali activated materials, State of the art report, RILEM TC 224-AAM, 2014

${ }^{4}$ R. Cioffi, F. Colangelo, F. Montagnaro, L. Santoro, Manufacture of artificial aggregate using MSWI bottom ash, Waste management, 31 (2010), 281-288, doi:10.1016/j.wasman.2010.05.020

${ }^{5}$ C. R. Cheeseman, A. Makinde, S. Bethanis, Properties of lightweight aggregate produced by rapid sintering of incinerator bottom ash. Resources, Conservation and Recycling, 43 (2005), 147-162, doi:10.1016/j.resconrec.2004.05.004

${ }^{6}$ F. Colangelo, C. Ferone, F. Messina, R. Cioffi, MSWI fly ash cementation by means of cold-bonding pelletization, $34^{\text {th }}$ Cement and Concrete Science Conference and Workshop on Waste Cementation, Sheffield, September 14-17, 2014

${ }^{7}$ F. Colangelo, F. Messina, R. Cioffi, Recycling of MSWI fly ash by means of cementitious double step cold bonding pelletization: Technological assessment for the production of lightweight artificial sggregates, Journal of Hazardous Materials, 299 (2015), 181-191, doi:10.1016/j.jhazmat.2015.06.018

${ }^{8}$ G. Baykal, A. G. Dovan, Utilization of fly ash by pelletization process: theory, application areas and research results, Resources Conservation and Recycling, 30 (2000), 59-77, doi:10.1016/S09213449(00)00042-2

${ }^{9}$ S. Shanmugasundaram, S. Jayanthi, R. Sundararajan, C. Umarani, K. Jagadeesan, Study of utilization of fly ash aggregates in concrete, Modern Applied Science, 4 (2010) 5, 44-57

${ }^{10}$ C. Vengatachalapathy, S. Thirugnanasambandam, Fly ash - based lightweight aggregate concrete containing steel fibers and polyesters fibers, The IUP journal of structural engineering, 7 (2014) 2, 15

${ }^{11}$ N. U. Kockal, T. Ozturan, Characteristics of lightweight fly ash aggregates produced with different binders and heat treatments, Cement and Concrete Composites, 33 (2011), 61-67, doi:10.1016/ j.cemconcomp.2010.09.007

${ }^{12}$ M. Gesoglu, E. Guneyisi, H. O. Oz, Properties of light weight aggregates produced with cold-bonding pelletization of fly ash and ground granulated blast furnace slag, Materials and Structures, 45 (2012), 1535-1546, doi:10.1617/s11527-012-9855-9

${ }^{13}$ C. Ferone, F. Colangelo, F. Messina, F. Iucolano, B. Liguori, R. Cioffi, Coal combustion wastes reuse in low energy artificial aggregates manufacturing, Materials, 6 (2013), 5000-5015, doi:10.3390/ma6115000

${ }^{14}$ J. M. J. M. Bijen, Manufacturing processes of artificial lightweight aggregates from fly ash, International Journal of Cement Composites and Lightweight Concrete, 8 (1986) 3, 191-199, doi:10.1016/02625075(86)90040-0 


\section{MATERIALI IN TEHNOLOGIJE/MATERIALS AND TECHNOLOGY (1967-2017) - 50 LET/50 YEARS}

\section{A. FRANKOVIČ et al.: LIGHTWEIGHT AGGREGATES MADE FROM FLY ASH ...}

${ }^{15}$ S. Geetha, K. Ramamurthy, Reuse potential of low-calcium bottom ash as aggregate through pelletization. Waste Management, 30 (2010) 8-9, 1528-1535, doi:10.1016/j.wasman.2010.03.027

${ }^{16}$ K. Ramamurthy, K. I. Harikrishnan, Influence of binders on properties of sintered fly ash aggregate, Cement and concrete cmposites, 28 (2006), 33-38, doi:10.1016/j.cemconcomp.2005.06.005

${ }^{17}$ K. I. Harikrishnan, K. Ramamurthy, Influence of pelletization process on the properties of fly ash aggregates, Waste management, 26 (2006), 846-852, doi:10.1016/j.wasman.2005.10.012

${ }^{18}$ R. Manikandan, K. Ramamurthy, Effect of curing method on characteristics of cold bonded fly ash aggregates, Cement and concrete composites, 30 (2008), 848-853, doi:10.1016/j.cemconcomp.2008. 06.006

${ }^{19}$ R. Manikandan, K. Ramamurthy, Influence of fineness of fly ash on the aggregate pelletization process, Cement and concrete composites, 29 (2007), 456-464, doi:10.1016/j.cemconcomp.2007.01.002

${ }^{20}$ EN 13055-1:2002, Lightweight aggregates, Part 1, Lightweight aggregates for concrete, mortar and grout

${ }^{21} \mathrm{~K}$. Kovler, Internal curing of Concrete- Effect of internal curing on autogenous deformation, RILEM TC 196-ICC: State-of-the-Art Report, RILEM Publications, S.A.R.L. (2007), 71-104

${ }^{22} \mathrm{O}$. M. Jensen, Internal curing of Concrete - Mechanisms of internal water curing, RILEM TC 196-ICC: State-of-the-Art Report, RILEM Publications, S.A.R.L., (2007), 15-27

${ }^{23}$ P. Lura, O. M. Jensen, S. I. Igarachi, Internal curing of concrete Experimental methods to study internal water curing, RILEM TC 196-ICC: State-of-the-Art Report, RILEM Publications, S.A.R.L., (2007), 57-69

${ }^{24}$ A. Elsharief, M. D. Cohen, J. Olek, Influence of lightweight aggregate on the microstructure and durability of mortar, Cement and concrete research, 35 (2005), 1368-1376, doi:10.1016/j.cemconres. 2004.07.011

${ }^{25}$ M. Gesoglu, T. Ozturan, Shrinkage cracking of lightweight concrete made with cold-bonded fly ash aggregates, Cement and concrete research, 34 (2004), 1121-1130, doi:10.1016/j.cemconres.2003. 11.024
${ }^{26}$ N. U. Kockal, T. Ozturan, Durability of lightweight concrete with lightweight fly ash aggregates, Construction and building materials, 25 (2011), 1430-1438, doi:10.1016/j.conbuildmat.2010.09.022

${ }^{27}$ N. U. Kockal, T. Ozturan, Effects of lightweight fly ash aggregate properties on the behaviour of lightweight concretes, Journal of hazardous materials, 197 (2010), 954-965, doi:10.1016/j.jhazmat. 2010.03.098

${ }^{28}$ R. Wasserman, A. Bentur, Effect of lightweight fly ash aggregate microstructure on the strength of concretes, Cement and concrete research, 27 (1997) 4, 525-537, doi:10.1016/S0008-8846(97) 00019-7

${ }^{29}$ A. Terzić, L. Pezo, V. Mitić, Z. Radojević, Artificial fly ash based aggregates properties influence on lightweight concrete performances, Ceramics international, 41 (2015), 2714-2726, doi:10.1016/j.ceramint.2014.10.086

${ }^{30}$ EN-450-1, Fly ash for concrete, Part 1, Definition, specifications and conformity criteria, 2013

${ }^{31}$ A. Sivakumar, P. Gomathi, Pelletized fly ash lightweight aggregate concrete: A promising material, Journal of Civil Engineering and Construction Technology, 3 (2012), 42-48, doi:10.5897/ JCECT11.088

${ }^{32}$ EN 196-1:2005, Methods of testing cement, Part 1: Determination of strength

${ }^{33}$ SIST 1026:2008, Concrete, Part 1: Specification, performance, production and conformity - Rules for the implementation of SIST EN 206-1

${ }^{34}$ EN 206:2013, Concrete, Specification, performance, production and conformity

${ }^{35}$ EN 1745:2012, Masonry and masonry products, Methods for determining thermal properties

${ }^{36}$ C.G. Rocco, M. Elice, Effect of aggregate shape on the mechanical properties of a simple concrete, Engineering Fracture Mechanics, 76 (2009) 2, 286-2987, doi:10.1016/j.engfracmech.2008.10.010

${ }^{37}$ J. Mao, K. Ayuta, Freeze - Thaw Resistance of Lightweight Concrete and Aggregate at Different Freezing Rates, Journal of Materials in Civil Engineering, (2008) 78-84, doi:10.1061/(ASCE)08991561(2008)20:1(78) 